\title{
Albanon
}

Revistë kulturore

\section{Aktualiteti i Normales, një vlerë universale}

\author{
Liman VAROSHI \\ Mustafa KADZADEJ
}

Themelimi i shkollës së parë të mësuesisë në Shqipëri, të cilën të gjithë e njohim me emrin Normalja e Elbasanit, është një prej ngjarjeve çelës, etapë e pashmangshme në kalendarin e zhvillimit historik dhe kulturor të popullit shqiptar.

Hapja e Shkollës Normale me të drejtë është cilësuar si një prej vendimeve më të rëndësishme të Kongresit të Elbasanit, i cili, bashkë me Kongresin e parë dhe të dytë të Manastirit, ishin dëshmi, para vetes dhe para botës, se kombi shqiptar po përgatitej për një periudhë të re historike në jetën e tij, për pavarësimin politik dhe shtetëror. Për hirë të së vërtetës theksojmë se Kongresi Kombëtar i Elbasanit është vështruar nga studiuesit e sotëm në të gjithë paradigmën e tij, pa kufizime të çfarëdolloji, me liri shkencore dhe akademike, duke bërë të mundur rivlerësimin e tij në historinë e Shqipërisë, duke i njohur atij merita të papërsëritshme, si një nyjë kyçe midis Kongresit të Alfabetit dhe Kuvendit Historik të Shpalljes së Pavarësisë. Madje, si rrjedhojë e këtij kontributi janë ndriçuar figura e personalitete të këtij kongresi, që koha i pati lënë në hije, për të mos thënë në errësirë, për shkak të disiplinës së rreptë ideologjike.

Gjithashtu studiuesit kanë kontribuar jo pak edhe në drejtim të ripërcaktimit të vendit të shkollës Normale, jo vetëm në historinë e arsimit shqiptar, por edhe në të gjithë historinë e jetës shpirtërore të shqiptarëve përgjatë shekullit XX, brenda Shqipërisë politike, por edhe jashtë saj. Kështu, studiuesi i mirënjohur elbasanas T. Plangarica, në një punim kushtuar Normales ka mundur që përmes argumenteve bindëse t’i përcjellë lexuesit dimensionin intelektual që institucioni i Normales krijoi dhe përvijoi gjatë gjithë historisë së ekzistencës dhe funksionimit të tij. Ndërsa një ndër studiuesit më të njohur të historisë së arsimit shqiptar profesor H.Myzyri, në veprën 
e titulluar "Shkolla Normale e Elbasanit" arrin që përmes burimeve dokumentare të identifikojë atë kompleks faktorësh, të cilët me veprimin e tyre kushtëzuan krijimin dhe funksionimin e shkollës Normale në rrjedhë të historisë. Pjesë e këtij kontributi rezulton edhe muzeologu i njohur elbasanas Genc Trandafili, i cili nëpërmjet grumbullimit dhe ekspozimit të fakteve dokumentare, relikeve dhe objekteve të ndryshme ka mundur të transmetojë krejt natyrshëm vlerat e Normales jo vetëm në qytetin e saj të lindjes, por edhe më gjerë. Interesant në evidentimin e profilit që krijoi dhe përvijoi shkolla Normale në drejtim të përhapjes së arsimit dhe diturisë në trevat shqiptare, rezulton edhe kontributi i elbasanasit Mehmet Gjevori, i cili për shumë vite punoi dhe jetoi në Kosovë.

Të ndërgjegjshëm për shumësinë e vlerave që përmban dhe ofron Normalja, si dhe për të mos përsëritur ato ç'ka janë thënë për të nga studiues të ndryshëm, mendojmë se vëmendja duhet përqendruar tashmë në identifikimin dhe promovimin e atyre vlerave të cilat kontribuojnë dukshëm në ripërcaktimin gjithnjë e më real të vendit që meriton kjo shkollë në historinë e arsimit shqiptar. Si të tilla do të veçonim:

Së pari- Historia e arsimit në Shqipëri ende nuk është shkruar siç e meriton, sepse shumë shpesh pohohet se pavarësia jonë u arrit me pushkë e me penë, por një histori e mendimit shqiptar dhe e rolit të tij në jetën kombëtare ende mungon.

E parë në kontekstin ideologjik, historia e arsimit dhe e shkollës shqiptare është mbyllur në kornizat e laicitetit, që jo vetëm në Shqipëri, por edhe në vendet më të përparuara, është një fazë shumë e vonshme e këtij procesi.

Herët a vonë, por sa më shpejt aq më mirë, studimet që duhet të ndërmerren në këtë fushë, do të na bëjnë të ditur se cili ka qenë roli i seminareve dhe kolegjeve, i shkollave në shqip e në gjuhë të huaj, që paraprinë dhe përgatitën arsimin kombëtar në gjuhën amtare. Mendojmë se vetëm kështu fitojnë natyrshmëri të gjitha lëvizjet e kryera në funksion të zhvillimit të arsimit kombëtar në përgjithësi dhe në atë të Normales në veçanti.

Por, sido që të rishikohet dhe sado të pasurohet historia e shkollës, pikëpamja jonë shkon në favor të faktit se vendi i Normales së Elbasanit vetëm do të lartësohet. Ajo i ka bërë vend vetes, jo vetëm si projekt i rilindjes kombëtare, jo vetëm si hap vendimtar drejt pavarësisë, por dhe si një institucion me të cilin lidhet historia e emancipimit të shqiptarëve. 


\section{Albanon}

Revistë kulturore

Së dyti- Normalja presupozon një shkollë-shenjë, që ka brenda historisë së vet lavdinë e disa brezave. Nga kjo shkollë kanë dalë studiues të shquar, albanologë, shkrimtarë me njohje mbarëkombëtare, artistë dhe veprimtarë publikë, qytetarë të denjë të atdheut të vet dhe shtetarë me kulturë klasike europiane dhe shqiptare. Koncepti ynë identifikon dhe afirmon faktin se në mbi një shekull shkollë kombëtare ka përvoja të vlefshme për çdo kohë. Në këtë kontekst, theksojmë se institucioni i Normales parapriu reformat e mëdha shekullarizuese dhe kombëtarizuese të viteve 1930-të, mundësoi hapjen shkallë-shkallë të arsimit në të gjithë vendin, përhapi kultin e shkollës dhe mitin e dijes në të gjithë botën shqiptare, edukoi shpirtin e qëndresës dhe identitetin shqiptar. Rrjedhimisht të gjithë këta tregues do të shërbenin si tema të parapëlqyera për të gjithë studiuesit.

Së treti- Antifashizmi i reflektuar nga Normalja dhe normalistët në vitet e Luftës së Dytë Botërore do të përbënte një argument interesant për studiuesit e fushës së historisë. Sikurse dihet antifashizmi i shfaqur në këtë periudhë në krejt treguesit e tij përmbajtësor rezulton kompleks. Ndaj, evidentimi dhe interpretimi i tyre do të kërkonte hulumtim të shumanshëm dokumentar dhe studim të thelluar dhe të kualifikuar. Gjithashtu trajtimi i këtij antifashizmi duhet bërë hap pas hapi dhe në kontekste të caktuara kohore historike. Vetëm kështu do mund t'i afrohemi të vërtetës historike dhe të shmangim subjektivizmin dhe politizimin në procesin e studimit të këtij problemi. Pa pretenduar se po bëjmë profetin pikëpamja jonë shkon në favor të vlerësimit se antifashizmi i Normales dhe i normalistëve është evident. Siç dihet gjatë kësaj periudhe u krijua mundësia që shkollat shqipe të hapeshin edhe në Kosovë e Maqedoni, ku mbi 180 arsimtarë, pjesa më e madhe e të cilëve normalistë e ish-normalistë, shkuan vullnetarisht atje ku shpirti dhe fryma e normales duhej të ngjallnin fjalën shqipe, shkrimin shqip, vetëdijen kombëtare. Po në ato vite, brezi më ri i normalistëve do të jepte shembuj të lartë të antifashizmit, si qëndrimi më i drejtë i përshtatur për kohën. Dhjetëra djem dhe vajza, brenda një dite, lanë librat dhe morën armët për të mbrojtur nderin e vendit dhe lirinë e atdheut. 
Së katërti- Në kohën e sotme arsimi po njeh zhvillime që nuk mund të mendoheshin më parë. Në gjithë shumëllojshmërinë e këtyre zhvillimeve vlen të theksohet prirja shumë e vlerësueshme e kthimit tek modelet e dikurshme të shkollave klasike, që sistemi unik arsimor i periudhës totalitare i pati shuar, si licetë dhe kolegjet. Është fakt i pakundërshtueshëm se në përvojën e krijuar prej shkollave klasike në Shqipëri, Normalja zë vend qendror. Për më tepër, arsimi parauniversitar dhe ai universitar, aktualisht, kanë ndryshuar shumë jo vetëm në dije e metodologji, por edhe në teknika. Jemi të bindur se këto ndryshime e bëjnë domosdoshmëri krijimin dhe përvijimin e raporteve funksionale ndërmjet procesit të mësimdhënies dhe atij të mësimnxënies. Normalja ofron një model tejet produktiv në këtë drejtim. Identifikimi i një modeli të tillë nuk mund të përceptohet pa vështruar dhe studiuar në të gjithë treguesit përbërës kornizën kurrikulare që Normalja krijoi dhe përvijoi në trajtë graduale. Themi kështu për faktin se kurrikula e kësaj shkolle njohu një proces evolucioni tejet interesant dhe ju përshtat standardeve të kohës si rrjedhojë edhe e kontributit që sillnin të shkolluarit në institucionet arsimore me orientim gjerman dhe francez. Përshtatja ndaj standardeve më të arrira të kohës i mundësoi Normales zhvillimin e një procesi mësimor që në përmbajtjen e tij të kishte jo vetëm të mësuarin llogjik dhe krijues, por edhe të menduarit kritik. Pa hyrë në kompetencën e studiuesve të fushës së metodologjisë së mësimdhënies, do të ndaleshim posaçërisht në dy programe mësimore lëndore, të cilat nuk rezultonin pjesë përbërëse e formimit bazë të nxënësve. Kështu, në mjediset e ADE-së ndeshëm në dy programe mësimore që kishin të bënin me edukimin fizik dhe artistik. Të dy këto programe përfaqësonin modelet e shkollës gjermane e në rastin konkret asaj të Berlinit. Ajo që na tërhoqi vëmendjen kishte të bënte me programin e edukimit artistik ku krahas edukimit muzikor i njohur tashmë, ishte edhe edukimi me elementët fillestar të mjeshtërisë së aktorit, e cila realisht përbën një risi dhe ruan aktualitetin.

Rrjedhimisht, vështrime të tilla sinergjike, historiko-shkencore, mendojmë se janë jo vetëm çështje të dijes, por edhe në shërbim të reformës së shumanëshme në të cilën gjendet procesi mesimor dhe kërkimor në universitet. Për me tepër ato jo vetëm mundësojne aktualitetin e vlerave që 


\section{Albanon}

\section{Revistë kulturore}

ofron Normalja, por i japin atyre edhe karakter universal.

Ndërkaq, Normalja e Elbasanit mund të cilësohet pa mëdyshje si institucioni me rolin më të rëndësishëm iluminist gjatë gjysmës së parë të shekullit të 20-të. Ajo përgatiti rrethanat që, më së fundi, edhe Shqipëria të bëhej një vend me universitet dhe me shkolla të larta. Në këtë kontekst, Normales mund t'i njihet merita e padiskutueshme si shkolla e mësuesve të mësuesve, e cila lartësoi arsimin shqiptar në rrugën e rritjes, duke qenë edhe vetë një institucion që kreu për kohën funksionet e një universiteti. Kalimi i natyrshëm i saj në Institut i lartë pedagogjik dhe më pas në Universitet $\mathrm{i}$ përngjan dukurisë së rrathëve koncentrikë, ku tri rrathët simbolizojnë tri institucione, përkatësisht Normalen, Institutin dhe Universitetin, kurse qendra e tyre truallin e begatë kulturdashës dhe arsimdashës të Elbasanit, të cilin Luigj Gurakuqi me të drejtë e cilësonte jo vetëm si "mesi i Shqipërisë landore, por edhe mesi i Shqipërisë mendore".

Diploma e Normales së Elbasanit rezultoi një prej diplomave më të nderuara e më të vlerësuara të gjithë historisë së shkollës shqiptare. Kjo diplomë do të mbetet në kujtesën e disa brezave si çertifikatë krenarie, jo vetëm për mësuesit e nderuar që e fituan, por edhe për ata që përfituan prej tyre në të gjitha anët e Shqipërisë.

Nisur nga vlerësime të tilla, pa kurrfarë emocioni, entuziazmi të tepruar apo euforie të pamotivuar, personalisht jemi në favor të përcaktimit të Normales si tempull i dijes. Këta tempuj lindin pikërisht atje ku i kërkon shpirti i një kombi. Në këtë kontekst, Normalja lindi në Elbasan, sepse shpirti shqiptar e kërkoi në një mjedis me një traditë të pasur arsimi e diturie, në një qytet ku dashuria dhe pasioni për dije ishin mbi gjithçka. Pikërisht identifikimi i vlerës emancipuese të këtij qyteti nuk i ka shpëtuar edhe studiuesve të huaj, që nga kronikani i madh i Perandorisë Otomane i gjysmës së dytë të shekullit XVII-të, Evlija Çelebiu, dhe deri tek studiuesja e njohur britanike e fillimit të shekullit të XX-të, Edith Durham.

Në rreshtat e mësipërm theksuam se Universiteti i Elbasanit rrënjët i ka tek shkolla Normale. Të dy këto institucione në kuptimin metaforik janë gjymtyrë të të njejtit trup, janë pjesë e një vijimësie, që na bën përgjegjës për të nderuar traditën dhe për të mos e lënë të mjergullohet emrin e secilës prej këtyre gjymtyrëve, duke ndikuar për mirë tek njëra-tjetra.

Ndaj, është mëse e natyrshme të pohojmë se Universiteti i Elbasanit rezulton në vazhdimësi vlerash dhe funksionesh me Normalen. Vështrimi i kujdesshëm i procesit historik të krijimit dhe përvijimit të këtij institucioni 
universitar, jo vetëm reflekton të njëjtën linjë të ndjekur nga ekuivalentët europianë, por njëherësh konfirmon identitetin e tij historik në raport më të gjithë institucionet e kësaj natyre që ekzistojnë dhe funksionojnë në krejt hapësirën shqiptare. Si një institucion që e ndjek pas historia, strategjia e zhvillimit të tij ka vetëm një prirje, ecjen përpara përmes zhvillimeve të dukshme cilësore në funksion të përmbushjes së kërkesave që shtron tregu lokal dhe global i punës.

\section{Bibliografi}

1. Fondi arkivor i Muzeut të shkollës Normale.

2. Përmbledhje me studime "Normalja në Traditë", Reklama, 1995.

3. Edwin E.Jacques,"Shqiptarët”, vëll I, Kartë e Pendë,1996.

4. Përmbledhje me Studime, "Normalja në fokus të bashkëkohësisë", Silver, 1999.

5. Akademia e Shkencave të Shqipërisë, "Historia e Popullit Shqiptar", vëll II, Toena, 2002.

6. Hysni Myzyri,"Shkolla Normale e Elbasanit”, Tiranë, Albpaper, 2004.

7. Përmbledhje me studime,"Mendimi shqiptar dhe Shkolla Shqipe", Plejad, Tiranë, 2009.

8. Tomorr Plangarica, "Vlera të rishfaqura", Onufri, Tiranë, 2019. 